\title{
Comparative Anatomical and Micromorphological Studies on Some Species of Lathyrus L. Section Lathyrus (Papilionoideae, Fabaceae)
}

\author{
Hüseyin ÇİLDİR , Ahmet KAHRAMAN2, , Musa DOĞAN³, Hatice NURHAN BÜYÜKKARTAL ${ }^{4}$ \\ ${ }^{1}$ TED University, Faculty of Arts and Sciences, Basic Sciences Unit, 06420 Turkey \\ ${ }^{2} U$ şak University, Faculty of Arts and Sciences, Department of Biology, 64200 Turkey \\ ${ }^{3}$ Middle East Technical Univesity, Faculty of Arts and Sciences, Department of Biological Sciences, 06800 Turkey \\ ${ }^{4}$ Ankara Univesity, Faculty of Sciences, Department of Biology, 06100 Turkey
}

Received: 03.12 .2017

Accepted: 25.12 .2017

Available online: 26.12 .2017

Published: 29.12.2017

\begin{abstract}
Lathyrus L. (Papilionoideae, Fabaceae) is considered economically, ecologically, and genetically among the most significant genera of the flowering plants having its centre of diversity in Southwest Asia where Turkey is located. The anatomical and micromorphological characteristics of species of the genus Lathyrus have been reported in only a few studies. Thus, in the present study, comparative anatomy and leaf epidermal micromorphology of L. cassius Boiss., L. chloranthus Boiss. \& Balansa, L. cicera L., L. hirsutus L., and L. sativus L. belonging to the section Lathyrus of this genus are comprehensively investigated by light and scanning electron microscopy so as to assess the taxonomic importance of anatomical and micromorphological characters in species separation. The results obtained reveal that some anatomical and micromorphological characters have proved useful for discrimination at the species level. Anatomical and micromorphological properties of taxonomic significance are as follows: the number of ray rows in the root, the outline of the stem in transverse section, the ratio of the wing length to the stem diameter, the number of vascular bundles in each wing, the shape of leaf epidermal cells, the pattern of their anticlinal walls, and the presence/absence of trichomes on the leaf.
\end{abstract}

Keywords: Anatomy, Lathyrus, micromorphology, Turkey

\section{Lathyrus Cinsi Lathyrus Seksiyonundaki (Papilionoideae, Fabaceae) Bazı Türler Üzerine Karşılaştırmalı Anatomik ve Mikromorfolojik Çalışmalar}

Özet: Lathyrus L. (Papilionoideae, Fabaceae) ekonomik, ekolojik ve genetik olarak çiçekli bitkilerin en önemli cinsleri arasında kabul edilir ve Türkiye' nin bulunduğu Güneybatı Asya çeşitlilik merkezidir. Lathyrus cinsinde yer alan türlerin anatomik ve mikromorfolojik özellikleri sadece birkaç çalışmada bildirilmiştir. Bu yüzden, bu güncel çalışmada bu cinsin Lathyrus seksiyonuna ait L. cassius Boiss., L. chloranthus Boiss. \& Balansa, L. cicera L., L. hirsutus L. ve L. sativus L. türlerinin karşılaştırmalı anatomisi ve yaprak epidermal mikromorfolojisi tür ayrımında anatomik ve mikromofolojik karakterlerin taksonomik önemini değerlendirmek için ışık ve taramalı elektron mikroskobu kullanılarak ayrıntılı bir şekilde araştırılmıştır. Elde edilen sonuçlar bazı anatomik ve mikromorfolojik karakterlerin tür düzeyinde ayrım için faydalı olduğunu göstermiştir. Taksonomik öneme sahip anatomik ve mikromorfolojik özellikler şunlardır: kökteki ışın sıralarının sayısı, gövdenin enine kesitteki şekli, kanat uzunluğunun gövdenin çapına oranı, her bir kanattaki iletim demetlerinin sayısı, yapraktaki epidermal hücrelerin ve bunların antiklinal duvarlarının şekli ve tüylerin varlığı.

Anahtar kelimeler: Anatomi, Lathyrus, mikromorfoloji, Türkiye

\section{Introduction}

Fabaceae or Leguminosae, the third largest family of flowering plants with over 700 genera and 19.000 species, is composed of three subfamilies: monophyletic Papilionoideae and Mimosoideae and paraphyletic Caesalpinoideae. The cosmopolitan Papilionoideae is by far the largest subfamily with over 13.800 species (Lewis et al. 2005). Lathyrus L. belongs within this subfamily together with genera like Lens Mill., Pisum L, Vavilovia A. Fed., and Vicia L. Lathyrus is the largest legume genus with about 160 species and 47 subspecies, most of which are self-pollinating (Ghorbel et al. 2014). The eastern Mediterranean and Irano-Turanian regions are its main centers of diversity, with smaller centres in North and South America (Kupicha 1983). Species of Lathyrus are economically important as food and fodder crops, ornamentals, soil nitrifiers, dune stabilizers, significant agricultural weeds, and model organisms for genetic and ecological research (Kenicer et al. 2005).
Lathyrus is divided into 12 or 13 sections by many scientists (Czefranova 1971, Kupicha 1983, Asmussen and Liston 1998, Croft et al. 1999, ILDIS 2005, Leht 2009). Kupicha (1983), carried out a worldwide infrageneric classification, separated it into 13 sections on the basis of morphological properties: Aphaca (J.Mill.) Dumort., Clymenum (J.Mill.) DC. ex Ser., Lathyrostylis (Griseb.) Bässler, Lathyrus L., Linearicarpus Kupicha, Neurolobus Bässler, Nissolia (J.Mill.) Dumort., Notolathyrus Kupicha, Orobastrum Boiss., Orobon Tamamsch., Orobus (L.) Godr., Pratensis Bässler, and Viciopsis Kupicha. This classification has been supported by the most recent molecular phylogenetic investigations (Croft et al. 1999, Kenicer et al. 2005).

According to Kupicha's (1983) infrageneric classification, in Turkey Lathyrus comprises 66 species and 76 taxa belonging to eleven sections, except for the sections Neurolobus and Notolathyrus (Davis 1970, Davis et al. 1988, Güneş and Özhatay 2000, Genç and Şahin 2011, Güneş and Çırpıcı 2012, Güneş 2014). 24 taxa of Lathyrus 
are endemic to Turkey that is a main center of diversity for the genus in Eurasia with a high number of species. Members of the section Lathyrus contain annual, procumbent to climbing herbaceous plants and are characterized by winged stems in the upper part, tendrillous or rarely aristate leaves, one-paired elliptic to linear leaflets with paralel to pinnate-parallel veins, semisagittate stipules, one to several flowered peduncles, and glabrous or hairy legumes (Davis 1970).

There are a few investigations on the anatomy and leaf epidermal micromorphology of Lathyrus (Metcalfe and Chalk 1950, Kupicha 1975, Gaboreanu et al. 1998, Krstić et al. 2002, Mantar et al. 2003, Basconsuelo et al. 2011, Celep et al. 2011, Kahraman et al. 2014). However, the anatomy and leaf micromorphology of many species of Lathyrus have not been studied yet. The aims of the present study are, therefore, to carry out a detailed investigation on the anatomy and leaf micromorphology of some species of Lathyrus with the aid of light and scanning electron microscopy and to ascertain whether or not these characters provide valuable taxonomic evidence supporting their separation.

\section{Material and Methods}

Specimens of L. cassius Boiss., L. chloranthus Boiss. \& Balansa, L. cicera L., L. hirsutus L., and L. sativus L. assigned to the section Lathyrus of Lathyrus were collected from their natural habitats during extensive field studies in Turkey. The collected specimens were stored in the herbarium of the Department of Biological Sciences, at the Middle East Technical University (METU) in Ankara. The voucher specimens are presented in Tab. 1.

Anatomical investigations were performed using fresh specimens kept in $70 \%$ ethyl alcohol. The paraffin wax method was applied for preparing cross-sections of roots and stems. The sections were stained with safranin and fast green (Johansen 1944) with some modifications relating to staining time and amount of additions to the stains, and then mounted on slides using Entellan mounting medium. They were examined and photographed by means of a Leica DM1000 Light Microscope (LM) (Figs. 1-2).

Table 1: Collection data of Lathyrus specimens examined here from anatomical and micromorphological point of view.

\begin{tabular}{ll}
\hline \multicolumn{1}{c}{ Species } & Collection details \\
\hline L. cassius & $\begin{array}{l}\text { Sivas, Hafik to Bayat, } 1346 \mathrm{~m}, \text { 22.6.2010, } \\
\text { H.Çildir } 170\end{array}$ \\
L. chloranthus & Kirşehir, Kaman, Kalehöyük, $1050 \mathrm{~m}, 20.6 .2010$, \\
& H.Çildir 184 \\
L. cicera & Aksaray, Hasan Mountain, $1510 \mathrm{~m}, 23.5 .2010$, \\
& H.Çildir 125 \\
L. hirsutus & $\begin{array}{l}\text { Ankara, METU, near Biology department, 850 } \\
\text { m, 6.5.2010, H.Çildir 133a }\end{array}$ \\
& Ankara, near Lalahan, $1100 \mathrm{~m}, 6.5 .2009$, \\
L. sativus & H.Çildir 121a \\
\hline
\end{tabular}

The leaf epidermal micromorphology was investigated via a Leica S8AP0 Stereo Microscope (SM) and a QUANTA 400F Scanning Electron Microscope (SEM). After a number of specimens had been compared under
SM, three to six leaves were examined for each species under SEM, operated at accelerating voltages ranging from 15 to $20 \mathrm{kV}$ (Figs. 3-4). The diversity of the leaf epidermal attributes was examined on the basis of the variation in micromorphology of epidermal cells and trichome types. Terminology for the leaf epidermal micromorphology mainly follows Wilkinson (1979).

\section{Results and Discussion}

For the Lathyrus taxa studied, LM micrographs of anatomical cross-sections of the root and stem and SEM micrographs of the leaf epidermal micromorphology are presented in Figs. 1-4. The major anatomical characters assessed for their root and stem features are provided in Tabs. 2-3.

\subsection{Root anatomy}

The transverse sections of adult roots of all the species analyzed reveal secondary structures; however, sometimes primary structures including epidermis, cortex and the vascular cylinder sectored into xylem and phloem, as in the young root of L. hirsutus. In the young root of L. hirsutus, the epidermis is the outermost layer of the root and consists of uniseriate cells that lack cuticle and stomata and are rectangular or square in shape with thin walls. The cortex is composed of multiple layers of irregularly shaped, thin-walled cells with intercellular spaces. Xylem rays comprise 1-3 radial rows of parenchymatous cells that are variable in length and width. Xylem elements are found occupying the root centre. In adult roots, the vascular cambium develops and produces the secondary xylem on the inside of the cambium ring and the secondary phloem on the outside of the ring. Since they increase in girth due to secondary growth, the epidermal tissue is sloughed off and replaced with periderm consisting of phellem and phelloderm, both derived from the phellogen, a single-layered secondary meristem. A multiseriate cortex found below the periderm comprises parenchymatous cells that are different in shape and size. The cortex also contains prismatic crystals of calcium oxalate and multi-layered, thick-walled sclerenchymatous cells, occasionally in the phloem. Vessels are polygonal, rounded or oval in shape and have thick walls. Rays are uniseriate or multiseriate with 1-10 rows of rectangular or almost square cells. The most maximum number of the ray rows is 10 , as in $L$. cassius. The widest rays are recognized to form in near the middle of the xylem region, as observed in L. cassius and L. sativus. The root centre seems to be occupied by the parenchymatous cells and sometimes by xylem elements. In the central part of the root of L. cicera, a cavity is formed because pith cells are partially destroyed (Fig. 1, Tab. 2).

\subsection{Stem anatomy}

The outline of the stem transverse sections is rhombic, quadrate or rounded with two wing-like expansions shorter than the stem diameter or nearly equal to it. Also, it is usually ribbed, or not ribbed as shown in L. hirsutus. Two opposite main ribs are distinct whereas the other ribs are less distinct. The ratio between length of the wing-like expansions and the stem diameter is approxiametely 0.5 to 1 . 

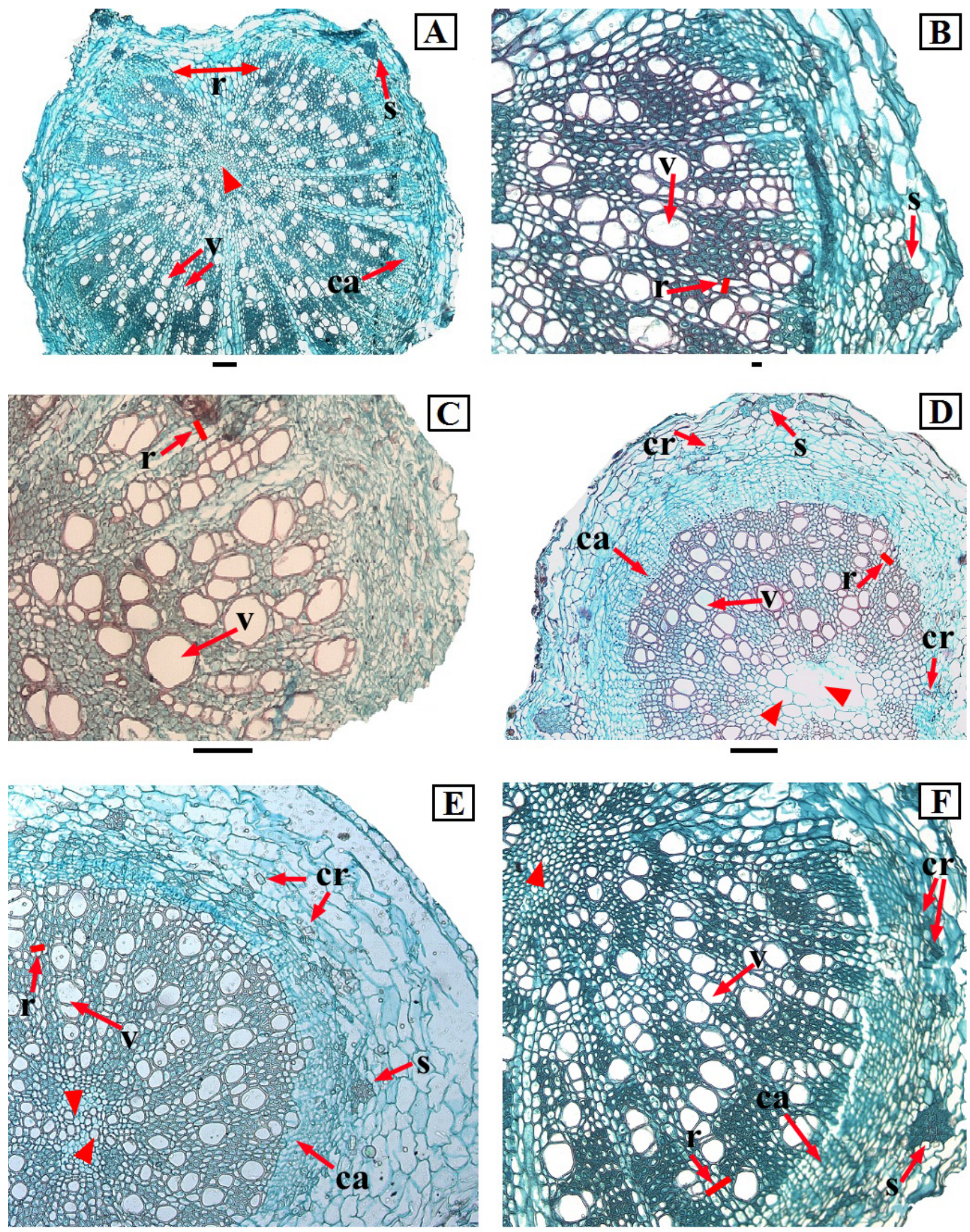

Figure 1: Light micrographs of transverse sections of the roots in the Lathyrus species studied. (A) L. cassius: the arrowhead indicates the root center occupied by parenchymatous cells, (B) Details of L. cassius, (C) L. chloranthus, (D) L. cicera: the arrowheads indicate the root center occupied by parenchymatous cells and a cavity, (E) L. hirsutus: the arrowheads show the root center occupied by the xylem, (F) $L$. sativus: the arrowhead shows the root center occupied by the parenchyma. Abbreviations: $c a=$ vascular cambium, $\mathrm{cr}=\mathrm{crystals,} \mathrm{r}=\mathrm{rays}, \mathrm{s}$ $=$ sclerenchymatous cells, $\mathrm{v}=$ vessels. Scale bars: $\mathrm{A}, \mathrm{C}-\mathrm{F}=100 \mu \mathrm{m}, \mathrm{B}=10 \mu \mathrm{m}$.

The epidermis consists of a single layer of tangentially elongated or almost square cells with the external wall moderately thicked and covered with a thin cuticle. As observed in assimilatory stems of L. cicera, L. hirsutus and L. sativus, a few layers of chlorenchyma (photosynthetic tissue) lie adjacent to the epidermis. 

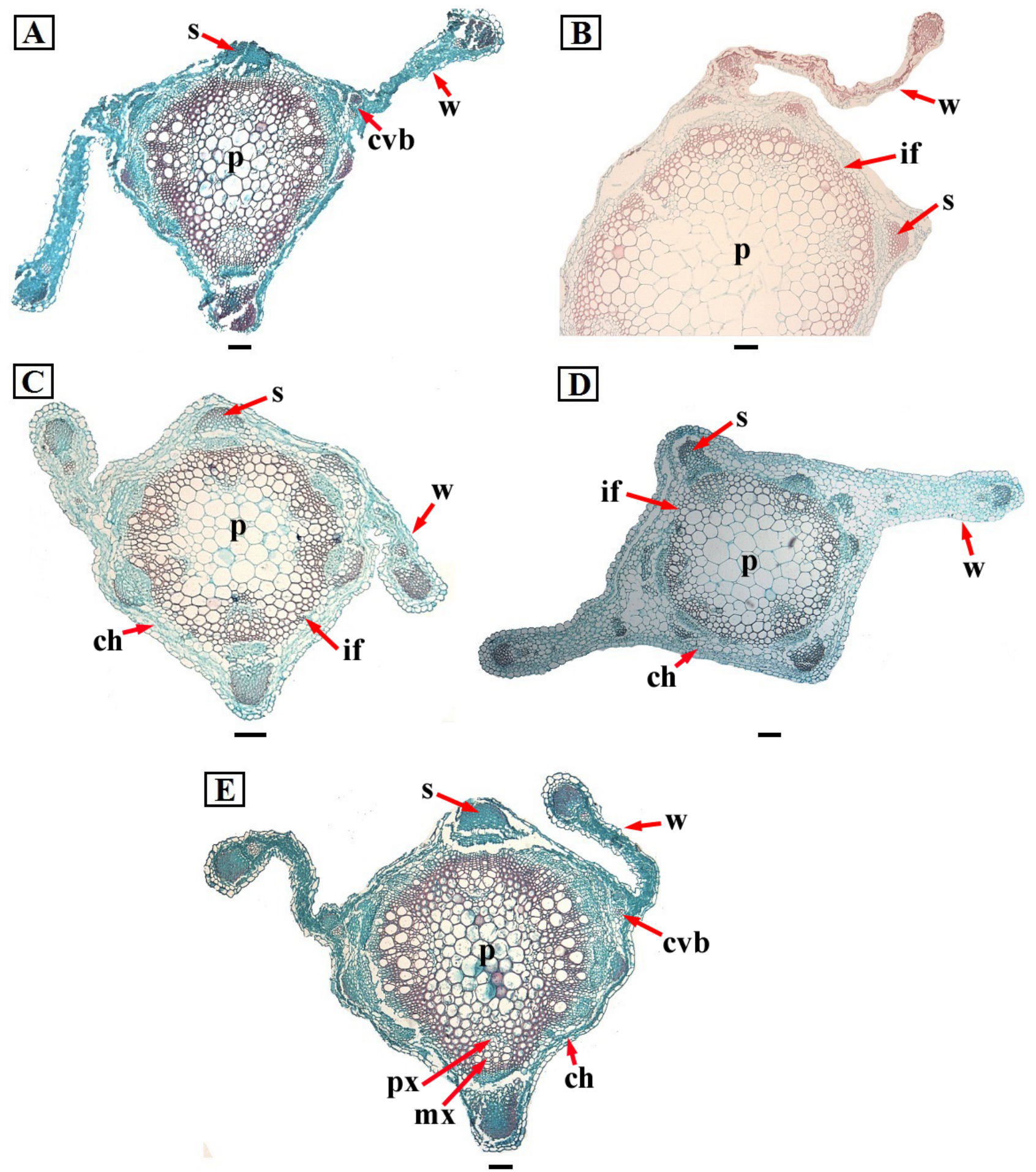

Figure 2: Light micrographs of transverse sections of the stems in the Lathyrus species studied. (A) L. cassius, (B) L. chloranthus, (C) L. cicera, (D) L. hirsutus, (E) L. sativus. Abbreviations: $\mathrm{ch}=$ chlorenchyma, $\mathrm{cvb}=$ cortical vascular bundle, if $=$ interfascicular fibres, $\mathrm{mx}=$ metaxylem, $\mathrm{px}=$ protoxylem, $\mathrm{s}=$ sclerenchymatous cells, $\mathrm{p}=$ pith, $\mathrm{w}=$ wing. Scale bars: $100 \mu \mathrm{m}$.

The cortex comprises of a few layers of slightly or considerably elongated parenchymatous cells with thin walls, and with or without intercellular spaces. Morever, it is often composed 1-3 layers of collenchymatous cells within ribs. L. chloranthus has the wider cortex than the other studied species Vascular tissues are organized in small and large collateral vascular bundles that are arranged in a ring at the periphery of the central cylinder and connected by interfascicular fibres. The vascular bundles opposite to the ribs are larger. The number of the bundles varies between 6 and 10. In addition to these bundles, there are often two cortical bundles located opposite to the wings. Also, there are 1-6 vascular bundles per wing. Above phloem, sclerenchyma fibers occur in groups and are more developed above larger bundles. The stem centre is occupied by a great pith (the largest pith in L. chloranthus) comprising polygonal and rounded, thin-walled parenchymatous cells with intercellular spaces (Fig. 2, Tab. 3).

\subsection{Leaf epidermal micromorphology}

Among the Lathyrus species studied, leaf epidermal cells show three types on the basis of cell shape and the pattern of anticlinal walls. 

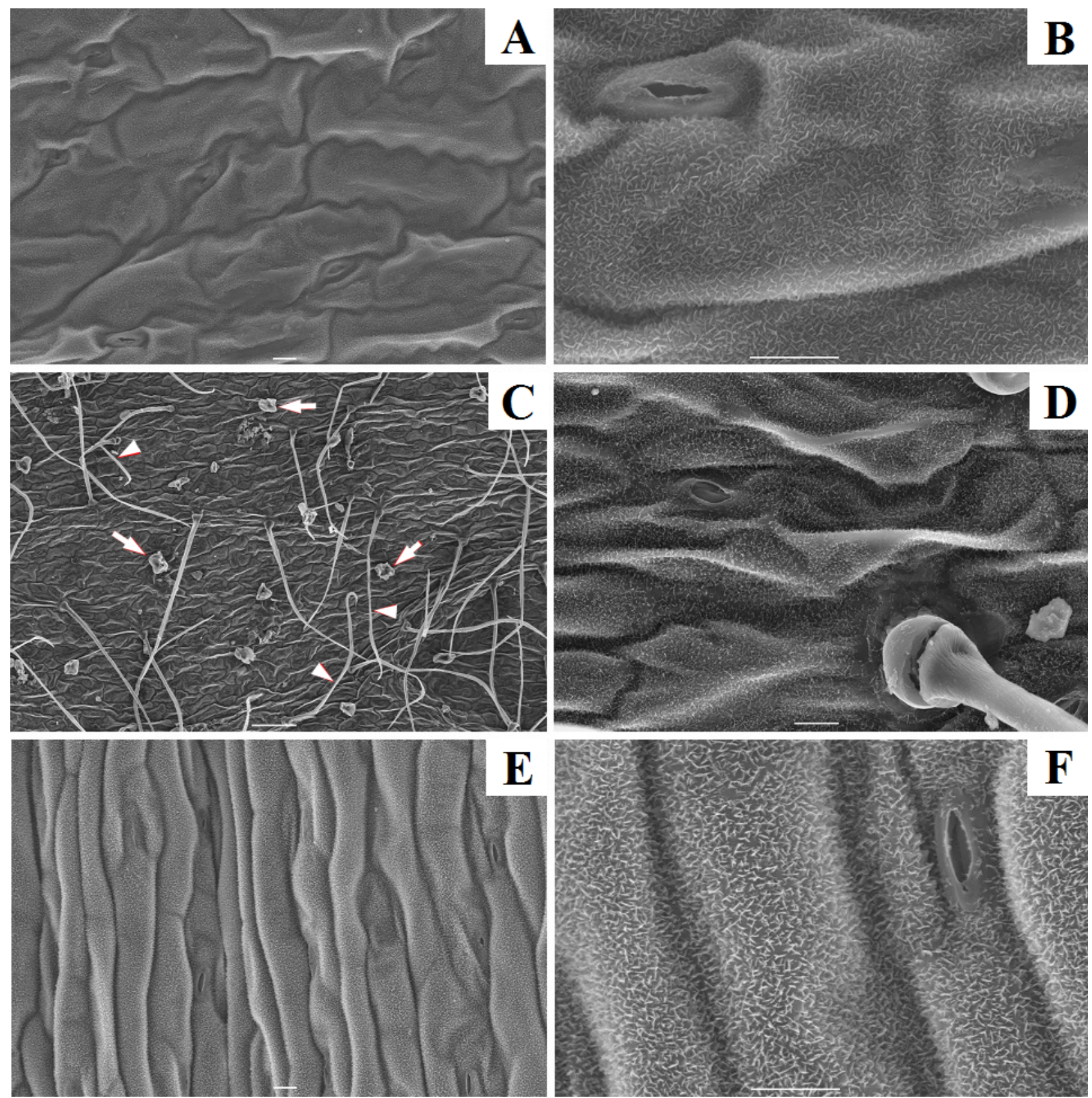

Figure 3: SEM micrographs showing the leaf micromorphology of the Lathyrus species studied. (A-B) L. cassius, (C-D) L. chloranthus: multicellular peltate glands (arrows) and short to long non-glandular trichomes (arrowheads), (E-F) L. cicera. Scale bars: A, B, D-F = 10 $\mu \mathrm{m}, \mathrm{C}=100 \mu \mathrm{m}$.

Table 2: Summary of the root anatomical properties of the Lathyrus species examined. Measurements are in $\mu$ m. Numbers refer to minimum-maximum (mean \pm standard deviation).

\begin{tabular}{|c|c|c|c|c|c|c|}
\hline Species & Number of ray rows & Length of ray cells & Width of ray cells & Length of cortex cells & Width of cortex cells & Dimeter of vessels \\
\hline L. cassius & (1-) 2-10 & $\begin{array}{l}19.63-75.43 \\
(39.35 \pm 15.70)\end{array}$ & $\begin{array}{l}8.32-37.25 \\
(21.41 \pm 8.73)\end{array}$ & $\begin{array}{l}9.08-38.62 \\
(20.55 \pm 7.32)\end{array}$ & $\begin{array}{l}21.12-88.35 \\
(49.00 \pm 19.12)\end{array}$ & $\begin{array}{l}15.95-78.06 \\
(39.72 \pm 18.54)\end{array}$ \\
\hline L. chloranthus & $1-4$ & $\begin{array}{l}19.33-37.27 \\
(26.75 \pm 6.47)\end{array}$ & $\begin{array}{l}6.54-15.81 \\
(11.35 \pm 2.86)\end{array}$ & $\begin{array}{l}10.40-27.34 \\
(19.96 \pm 5.57)\end{array}$ & $\begin{array}{l}22.41-48.80 \\
(33.96 \pm 8.16)\end{array}$ & $\begin{array}{l}24.03-89.73 \\
(43.53 \pm 19.78)\end{array}$ \\
\hline L. cicera & $1-6$ & $\begin{array}{l}14.84-32.95 \\
(23.79 \pm 5.77)\end{array}$ & $\begin{array}{l}6.94-15.52 \\
(11.77 \pm 2.58)\end{array}$ & $\begin{array}{l}11.84-21.14 \\
(15.60 \pm 2.59)\end{array}$ & $\begin{array}{l}14.84-65.53 \\
(40.25 \pm 17.37)\end{array}$ & $\begin{array}{l}17.01-61.31 \\
(35.08 \pm 12.71)\end{array}$ \\
\hline L. hirsutus & $1-3$ & $\begin{array}{l}17.41-27.70 \\
(23.10 \pm 3.78)\end{array}$ & $\begin{array}{l}7.10-14.70 \\
(10.27 \pm 3.05)\end{array}$ & $\begin{array}{l}14.54-31.63 \\
(22.94 \pm 5.41)\end{array}$ & $\begin{array}{l}28.78-90.05 \\
(49.48 \pm 19.13)\end{array}$ & $\begin{array}{l}12.83-45.05 \\
(30.06 \pm 10.43)\end{array}$ \\
\hline L. sativus & $1-6$ & $\begin{array}{l}20.24-69.89 \\
(34.26 \pm 16.73)\end{array}$ & $\begin{array}{l}8.24-39.73 \\
(17.37 \pm 8.35)\end{array}$ & $\begin{array}{l}12.82-35.71 \\
(21.31 \pm 7.29)\end{array}$ & $\begin{array}{l}18.10-101.76 \\
(50.40 \pm 21.20)\end{array}$ & $\begin{array}{l}13.01-59.01 \\
(32.98 \pm 12.20)\end{array}$ \\
\hline
\end{tabular}



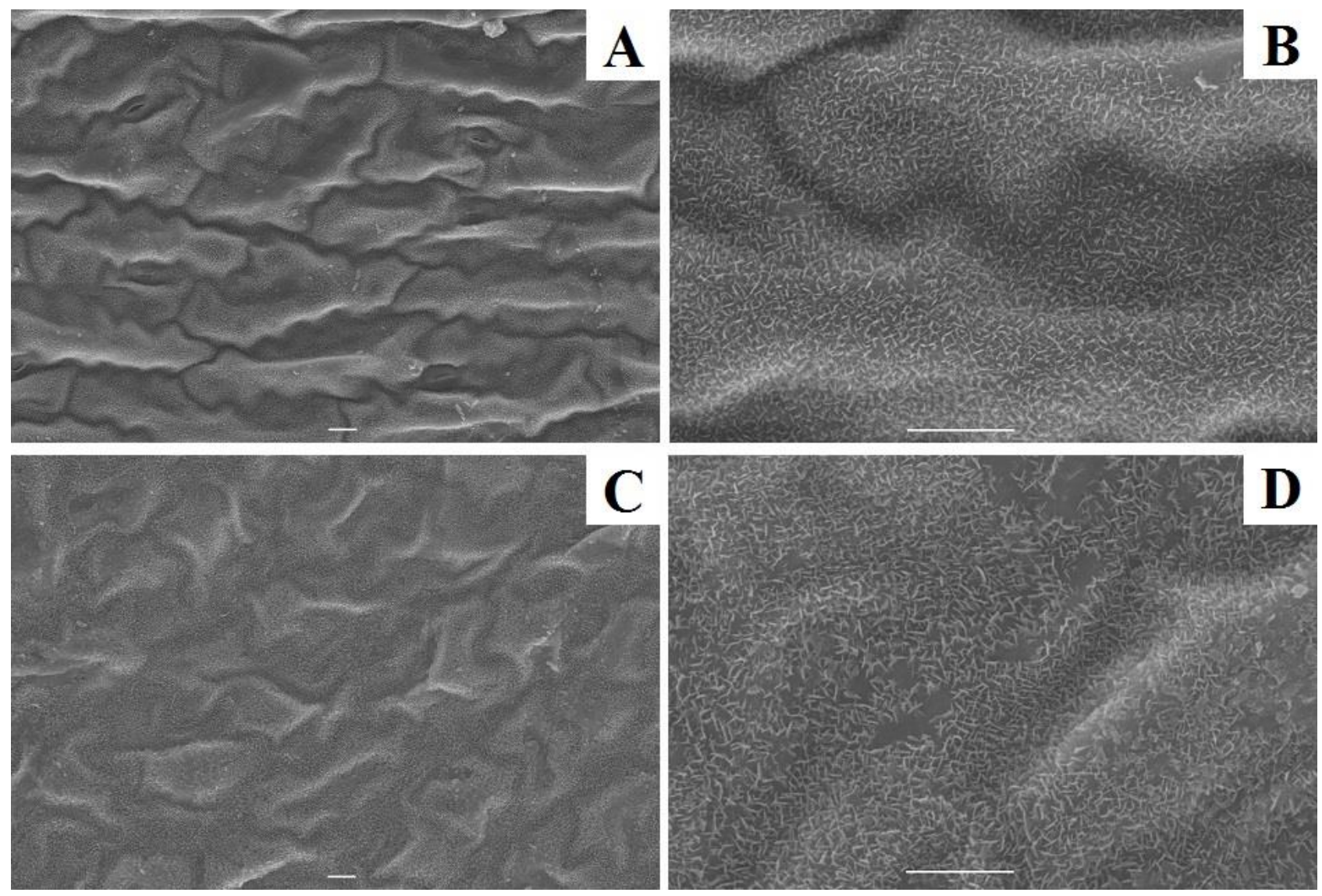

Figure 4: SEM micrographs showing the leaf micromorphology the Lathyrus species studied. (A-B) L. hirsutus, (C-D) L. sativus. Scale bars: $100 \mu \mathrm{m}$.

Table 3: Summary of the stem anatomical properties of the Lathyrus species examined. Measurements are in $\mu$ m. Numbers refer to minimum-maximum (mean \pm standard deviation).

\begin{tabular}{|c|c|c|c|c|c|c|}
\hline Species & $\begin{array}{l}\text { Outline of stem } \\
\text { transverse section }\end{array}$ & $\begin{array}{c}\text { Ratio of wing } \\
\text { length/stem } \\
\text { diameter }\end{array}$ & $\begin{array}{c}\text { Number of } \\
\text { vascular bundles } \\
\text { per wing }\end{array}$ & $\begin{array}{c}\text { Length of } \\
\text { epidermal cells }\end{array}$ & $\begin{array}{c}\text { Width of } \\
\text { epidermal cells }\end{array}$ & $\begin{array}{l}\text { Diameter of } \\
\text { pith cells }\end{array}$ \\
\hline L. cassius & Rhombic and ribbed & $2 / 3$ & 3 & $\begin{array}{l}17.10-31.00 \\
(20.03 \pm 5.23)\end{array}$ & $\begin{array}{c}20.03-57.81 \\
(36.05 \pm 9.87)\end{array}$ & $\begin{array}{c}23.15-87.79 \\
(50.60 \pm 21.02)\end{array}$ \\
\hline L. chloranthus & \pm Rounded and ribbed & $\sim 1$ & 6 & $\begin{array}{c}9.44-23.20 \\
(15.95 \pm 4.21)\end{array}$ & $\begin{array}{c}15.00-45.74 \\
(26.23 \pm 9.72)\end{array}$ & $\begin{array}{l}31.97-144.63 \\
(76.38 \pm 29.09)\end{array}$ \\
\hline L. cicera & \pm Rhombic and ribbed & $1 / 2$ & $1-2$ & $\begin{array}{c}8.00-26.82 \\
(18.56 \pm 5.08)\end{array}$ & $\begin{array}{c}16.01-43.44 \\
(27.44 \pm 8.09)\end{array}$ & $\begin{array}{c}14.74-78.21 \\
(37.72 \pm 18.68)\end{array}$ \\
\hline L. hirsutus & $\begin{array}{l}\text { Quadrate and not } \\
\text { ribbed }\end{array}$ & $2 / 3$ & 2 & $\begin{array}{c}9.80-31.92 \\
(19.38 \pm 7.29)\end{array}$ & $\begin{array}{c}14.93-39.65 \\
(26.68 \pm 7.49)\end{array}$ & $\begin{array}{c}20.30-108.91 \\
(60.47 \pm 20.85)\end{array}$ \\
\hline L. sativus & \pm Rhombic and ribbed & $2 / 3$ & 2 & $\begin{array}{c}12.16-26.79 \\
(17.05 \pm 4.73)\end{array}$ & $\begin{array}{c}20.08-57.69 \\
(35.76 \pm 11.60)\end{array}$ & $\begin{array}{c}20.08-86.54 \\
(51.48 \pm 19.82)\end{array}$ \\
\hline
\end{tabular}

L. cassius, L. chloranthus, and L. hirsutus possess elongated cells with distinctly undulate to sinuate anticlinal walls. In L. cicera, epidermal cells are much more elongated and their anticlinal walls are more or less straight. L. sativus has mostly isodiametric cells with obscurely undulate anticlinal walls. Most of the stomata are opened or partially closed. The leaf epidermal surface of all the species is glabrous or subglabrous, except L. chloranthus having many trichomes. On the leaf epidermal cells of $L$. chloranthus, there are two types of trichomes: peltate glandular and non-glandular trichomes. The peltate glandular trichomes have a basal cell embedded in the epidermis, a stalk cell and multicellular secretory head. The non-glandular trichomes are uniseriate, unbranched, short to long, and mostly multicellular. These nonglandular trichomes are straight or curved and sharppointed at the tip. The leaves of L. cicera, L. hirsutus and $L$. sativus do not often bear trichomes. However, short nonglandular trichomes are very sparcely distributed on some leaves of these species. 


\section{Discussion}

In the current study, valuable findings on the anatomy and leaf epidermal micromorphology of $L$. cassius, $L$. chloranthus, L. cicera, L. hirsutus, and L. sativus assigned to Lathyrus section Lathyrus are provided. The anatomical properties of the subfamily Papilionoideae and their significance for the taxonomic classification have been presented by some earlier studies (Metcalfe and Chalk 1950, Krishnamurthy and Kannabiram 1970, Kannabiram and Krishnamurthy 1974, Kothari and Shah 1975, Lackey 1978, Crow et al. 1997, Teixeira and Gabrielli 2006, Basconsuelo et al. 2011, Celep et al. 2011, Fortuna-Perez et al. 2012, Devecchi et al. 2014, Kahraman et al. 2014). Cutler (1976) and Patel (1965) point out that taxon identification based on root wood anatomy is not an easy task even for experienced wood anatomists and put emphasis on the difficulties represented by root wood studies due to the root system complexity. Legume root anatomy offers evidence for quite variable structures (Basconsuelo et al. 2011). Our findings on the root and stem anatomy of the species studied correspond with the previous investigations regarding the roots and stems of certain genera of the Papilionoideae (Metcalfe and Chalk 1950, Basconsuelo et al. 2011, Celep et al. 2011, Kahraman et al. 2014). The root and stem transverse sections of the species analyzed reveal that some anatomical characters are taxonomically important for distinguishing them from each other. Ray parenchyma cells are evolved to translocate nutrients radially between the phloem and the xylem (Basconsuelo et al. 2011). Rays in roots of the Papilionoideae are composed of 1-12-rowed cells but frequently 2-3 (Metcalfe and Chalk 1950). In L. cilicicus and L. nissolia the rays are up to 5-rowed (Celep et al. 2011, Kahraman et al. 2014). Ray characteristics observed in the species examined, such as the number of ray rows and the ray size, have taxonomic value. As an example, in L. cassius the maximum number of ray rows is 10; whereas, it is 6-rowed in L. cicera and L. sativus. The remaining species have 1-3 or 1-4 rows of rays. L. cassius and $L$. sativus have larger-sized ray cells than the other species. Vessels are medium-sized (100-200 $\mu \mathrm{m}$ mean tangential diameter) in most genera of the Papilionoideae (Metcalfe and Chalk 1950). Our study shows that the species have vessels varying from 12.83 to $89.73 \mu \mathrm{m}$. The smallest vessel diameter is observed in L. hirsutus. In the Papilionoideae the crystals, which are predominantly solitary but are very variable in size and shape, sometimes have a characteristic appearance and distribution, especially in the leaf epidermis. Crystalliferous cells frequently form a sheath along the outer boundary of the pericyclic sclerenchyma (Metcalfe and Chalk 1950). Solitary prismatic crystals are recognized to be distributed in the cortex of L. cicera, $L$. hirsutus, and L. sativus, rarely in the phloem.

In agreement with previous studies on the stem anatomy of Lathyrus (Krstić et al. 2002, Mantar et. 2003, Celep et al. 2011, Kahraman et al. 2014), all the studied species have a narrow stem cortex consisting of a few cell layers. Cortical vascular bundles in the cortex are found in a few species of the Papilionoideae, especially in winged or grooved stems (Metcalfe and Chalk 1950). In the cortex, there often occur cortical vascular bundles in the stems of the species studied. The presence/absence and structure of the wing-like expansions in the stems of
Lathyrus have taxonomic value in species delimitation (Metcalfe and Chalk 1950). The stems of L. maritimus Bigel and L. pratensis L. are flattened on one side and provided with two wings each containing a vascular bundle and their remaining vascular bundles are widely spaced and arranged in a flat circle around a pith cavity. L. sylvestris L. has a similar stem structure but its wings are much longer than these species, with several vascular bundles in each wing (Metcalfe and Chalk 1950). The stem crosssection of L. latifolius L. is elliptical with two wings longer than the stem diameter (Krstić et al 2002). On the other hand, there are no wings in L. cilicicus (Celep et al. 2011) and L. nissolia (Kahraman et al. 2014). In the present investigation, the species have stems with two wings each containing 1-6 vascular bundles. In $L$. chloranthus the number of vascular bundles per wing is 6 while it is 3 in L. cassius. The remaining species have one or two vascular bundles in each wing. The stem of L. chloranthus has two wings approximately equal to the stem diameter. The wing length is distinctly shorter than the stem diameter of L. cicera but the other species have somewhat shorter wings than the stem diameter. The outline of the stem transverse section is nearly rounded and ribbed in $L$. chloranthus whereas it is quadrate and not ribbed in $L$. hirsutus. The remaining species have rhombic and ribbed stems in outline.

Legumes bear different types of unicellular and multicellular trichomes, both secretory and non-secretory, on the vegetative (Franceschi and Giaquinta 1983, Retallack and Willson 1988, Shaheed and Illoh 2010) and floral organs (Guard 1931, Bernard and Singh 1969, Lersten and Brubaker 1987, Gunasinghe et al. 1988, Tucker 1997, Healy et al. 2005, de Freitas Mansano and de Pádua Teixeira 2008). The glandular and non-glandular trichomes are of various kinds; however, uniseriate nonglandular trichomes, each consisting of short basal cells and an elongated distal cell that are common in the Papilionaceae, have not been found in the Mimosaceae. In certain genera of the Papilionaceae, other kinds of nonglandular trichomes are two-armed, hooked, branched, and multicellular and shaggy. Two-armed hairs also occur in certain genera of the Caesalpiniaceae but appear to be absent in the Mimosaceae. In the Papilionaceae, the glandular trichomes might be club-shaped with long or short stalks and with specially large, spherical heads (Metcalfe and Chalk 1950). In a great number of genera belonging to the subfamily Papilionoideae, the leaf epidermis is characterized by the common occurrence of angular folds in the anticlinal walls; by the development of papillae, particularly in the lower surface (Metcalfe and Chalk 1950). Results of the present study show that the presence/absence, type, and size of trichomes on leaves are useful in delimiting the species. For example, $L$. chloranthus is easily diffentiated by short and long nonglandular trichomes and peltate glandular trichomes on its leaves from the remaining species studied. Trichomes appear to be absent in L. cassius. L. hirsutus has elongated cells and anticlinal walls with distinctly undulate to sinuate but $L$. cicera has much more elongated epidermal cells with more or less straight anticlinal walls. In $L$. sativus, epidermal cells are mostly isodiametric cells and their anticlinal walls are obscurely undulate.

In conclusion, this study provides comprehensive information on anatomical and leaf epidermal 
characteristics of some Lathyrus species that are useful for species identification. However, taking into account a large number of species in Lathyrus, further studies on other sections of this genus are required to corroborate our findings.

Acknowledgments: We wish to thank the Scientific Research Projects Coordination Unit of the Middle East Technical University for financial support and the curators of the following herbaria for allowing us to study their Lathyrus collections: ANK, CUFH, E, GAZI, HUB, K and KNYA.

\section{References}

Asmussen, C., Liston, A. 1998: Chloroplast DNA characters, phylogeny and classification of Lathyrus (Fabaceae). American Journal of Botany, 85: 387-401.

Basconsuelo, S., Grossoa, M., Molina, M. G., Malpassia, R., Kraus, T., Bianco, C. 2011: Comparative root anatomy of papilionoid legumes. Flora, 206: 799-807.

Bernard, R. L., Singh, B. B. 1969: Inheritance of pubescence type in soybeans: glabrous, curly, dense, sparse, and pubescent. Crop Science, 9: 192-197.

Celep, F., Çildir, H., Kahraman, A., Doğan, M., Cabi, E. 2011: Morphological and anatomical properties of Lathyrus cilicicus Hayek \& Siehe (sect. Platystylis, Fabaceae) from the Mediterranean region of Turkey. Australian Journal of Crop Science, 5 (2): 223-226.

Croft, A. M., Pang, E. C. K., Taylor, P. W. J. 1999: Molecular analysis of Lathyrus satious L. (grasspea) and related Lathyrus species. Euphytica, 107: 167-176.

Crow, E., Stirton, C. H., Cultler, D. F. 1997: Leaf anatomy of the genus Psoralea sensu stricto (Psoraleeae, Papilionoideae, Leguminosae). Botanical Journal of the Linnean Society, 124: 155-182.

Cutler, D. F. 1976: Variation in root wood anatomy. Leiden Botanical Series, 3: 143-156.

Czefranova, Z. V. 1971: Review of the species of the genus Lens Mill. Novosti Sistematiki Vyshikh Rastenii, 8: 197-204.

Davis, P. H. 1970: Lathyrus L. In: Davis, P. H. (ed.), Flora of Turkey and the East Aegean Islands, vol. 3, pp. 328-369. Edinburgh, UK: Edinburgh University Press.

Davis, P. H., Mill, R. R., Kit, T. 1988: Flora of Turkey and East Aegean Islands, vol. 10, pp. 125-126. Edinburgh, UK: Edinburgh University Press.

de Freitas Mansano, V., de Pádua Teixeira, S. 2008: Floral anatomy of the Lecointea clade (Leguminosae, Papilionoideae, Swartzieae sensu lato). Plant Systematics and Evolution, 273: 201-209.

Devecchi, M. F., Pirani, J. R. Melo-de-Pinna, G. F. A., 2015: Comparative leaf anatomy and morphology of some Brazilian species of Crotalaria L. (Leguminosae: Papilionoideae: Crotalarieae). Acta Botanica Brasilica, 28 (4): 583-593.

Fortuna-Perez, A. P., Castro, M. M., Tozzi, A. M. G. A. 2012: Leaflet secretory structures of five taxa of the genus Zornia J.F. Gmel. (Leguminosae, Papilionoideae, Dalbergieae) and their systematic significance. Plant Systematics and Evolution, 298 (8): 1415-1424.

Franceschi, V. R., Giaquinta, R. T. 1983: Glandular trichomes of soybean leaves: cytological differentiation from initiation to senescence. Botanical Gazette, 144: 175-184.

Gaboreanu, I., Florincescu, A., Moldovan, A. 1998: Morpho-anatomical aspects of the epiderm in two species of Lathyrus. Notulae Botanicae Horti Agrobotanici Cluj-Napoca, 27: 11-16.

Genç, H., Şahin, A. 2011: A new species of Lathyrus L. (Fabaceae) from Turkey. Journal of Systematics and Evolution, 49 (5): 505-508.

Ghorbel, M., Marghali, S., Trifi-Farah, N., Chtourou-Ghorbel, N. 2014 Phylogeny of Mediterranean Lathyrus species using inter simple sequence repeats markers. Acta Botanica Gallica: Botany Letters, 161 (1): 91-98.

Guard, A. T. 1931: Development of floral organs of the soy bean. Botanical Gazette, 91: 97-102.
Gunasinghe, U. B., Irwin, M. E., Kampmeier, G. E. 1988: Soybean leaf pubescence affects aphid vector transmission and field spread of soybean mosaic virus. Annals of Applied Biology, 112: 259-272.

Güneş, F., Özhatay, N. 2000: Lathyrus L. In: Güner, A., Özhatay, N., Ekim, T., Baser, K. H. C. (eds.), Flora of Turkey and the East Aegean Islands, vol. 11, pp. 92-94. Edinburgh, UK: Edinburgh University Press.

Güneş, F., Çırpıc1, A. H. 2012: A new record for the flora of Turkey: Lathyrus atropatanus (Leguminosae). Turkish Journal of Botany, 36, 425.

Güneş, F. 2014: A new species of Lathyrus (Fabaceae) from Turkey. Pensee Journal, 76 (3): 339-350

Healy, R. A., Horner, H. T., Bailey, T. B., Palmer, R. G. 2005: A microscopic study of trichomes on gynoecia of normal and tetraploid clark cultivars of Glycine max and seven near-isogenic lines. International Journal of Plant Sciences, 166: 415-425.

ILDIS (International Legume Database and Information Service), 2005: http://www.ildis.org/ date accessed 1 Temmuz 2017.

Johansen, D. A. 1944: Plant Microtechnique. New-York: McGraw-Hill.

Kahraman, A., Çildir, H., Doğan, M. 2014: Macromorphology, micromorphology and anatomy of Lathyrus sect. Nissolia (Fabaceae) and their taxonomic significance. Proceedings of the National Academy of Sciences, India, Section B: Biological Sciences, 84: 407-417.

Kannabiran, B., Krisshnamurthy, K. H. 1974: Morphology of foliar epidermis and taxonomy of the genus Crotalaria. Phytomorphology, 24: 61-68.

Kenicer, G., Kajita, T., Pennington, R. T., Murata, J. 2005: Systematics and biogeography of Lathyrus (Leguminosae) based on internal transcribed spacer and cpDNA sequence data. American Journal of Botany, 92 (7): 1199-1209.

Kothari, M. J., Shah, G. L. 1975: Epidermal structures and ontogeny of stomata in the Papilionaceae (Tribe Hedysareae). Botanical Gazette, 136 (4): 372-379.

Krisshnamurthy, K. H., Kannabiran, B. 1970: A note on the secretory idioblasts of the foliar epidermis of Crotalaria restusa L. Current Science, 39: 262-263.

Krstić, B. D., Boža, P. P., Merkulov, L. S., Krstić, L. N., Pajević, S. P., Stanković, Ž. S. 2002: Morphological, anatomical and physiological characteristics of Lathyrus latifolius L. (Fabaceae). Proceedings for Natural Sciences, Matica Srpska Novi Sad, 103: 81-89.

Kupicha, F. K. 1975: Observations on the vascular anatomy of the tribe Vicieae (Leguminosae). Botanical Journal of the Linnean Society, 70: 231-242.

Kupicha, F. K. 1983: The infrageneric structure of Lathyrus. Notes from the Royal Botanic Garden, Edinburgh, 41 (2): 209-244.

Lackey, J. A. 1978: Leaflet anatomy of Phaseoleae (Leguminosae: Papilionoideae) and its relation to taxonomy. Botanical Gazette, 139 (4): 436-446.

Leht, M. 2009: Phylogenetics of Vicia (Fabaceae) based on morphological data. Feddes Repertorium, 120: 379-393.

Lersten, N, R,, Brubaker, C. L. 1987: Extrafloral nectaries in Leguminosae: review and original observations in Erythrina and Mucuna (Papilionoideae: phaseoleae). Bulletin of the Torrey Botanical Club, 114 (4): 437-447.

Lewis, G. M., Schrire, B., Mackinder, B., Lock, M. 2005: Legumes of the World. London, UK: Kew Press.

Mantar, N., Bağci, E., Şahin, A., Gür, N. 2003: Lathyrus sativus L. ve L. hirsutus L. (Fabaceae/Leguminosae) türleri üzerinde morfolojik, palinolojik ve anatomik bir çalışma. Fırat Üniversitesi Fen ve Müh Bilimleri Dergisi, 15 (3): 303-314.

Metcalfe, C. R., Chalk, L. 1950: Anatomy of the Dicotyledons, vol. 1, pp. 504-516. Oxford, UK: Clarendon Press.

Patel, R. N. 1965: A comparison of the anatomy of the secondary xylem in roots and stems. Holzforschung, 19: 72-79.

Retallack, B., Willson, J. H. M. 1988: Morphology, anatomy, and distribution of capitate glandular trichomes on selected Trifolium species. Crop Science, 28: 677-680. 
Shaheed, S. A., Illoh, H. C. 2010: A taxonomic study of some species in Cassiinae (Leguminosae) using leaf epidermal characters. Notulae Botanicae Horti Agrobotanici Cluj-Napoca, 38 (1): 21-27.

Teixeira, S. P., Gabrielli, A. C. 2006: Taxonomic value of foliar characters in Dahlstedtia Malme Leguminosae, Papilionoideae, Millettieae. Acta Botanica Brasilica, 20 (2): 395-403.

Tucker, S. C. 1997: Floral evolution, development, and convergence: the hierarchical-significance hypothesis. International Journal of Plant Sciences, 158: 143-161.

Wilkinson, H. P. 1979: The plant surface (mainly leaf). In: Metcalfe, C. R., Chalk, L. (eds), Anatomy of the Dicotyledons, vol. 2, pp. 97-114, 143161. Oxford: Clarendon Press. 